\title{
The 1994 ICPD in Cairo: Draconian Measures vs. the Empowerment of Women
}

\section{Jim Horner}

School of Business, Cameron University, USA

\section{Wagiha Taylor}

School of Business, Wilkes University, USA

\section{ABSTRACT}

Respect for the environment, concerns about population, and the drive toward an efficient and equitable resource allocation are important elements in a relevant and ethical study of economics. Serious problems arise, however, whenever attempts at social control are masked as environmental science and population economics. This paper suggests that economic progress, democracy, and the empowerment of women, better address global problems than do draconian measures.

\section{INTRODUCTION}

The United Nations International Conference on Population and Development (ICPD) takes place at 10-year intervals. The present time period is about mid-way between the last and the next conference. The ICPD assembled in Cairo during September of 1994 to integrate the issue of the empowerment of women with the global problems of population, development, and the environment. The congregation included some 20,000 participants from 170 countries. The Conference highlighted extreme disputes between the population establishment and anti-abortion groups, environmentalists and advocates of economic growth, industrialized nations and industrializing nations, feminists and fundamentalists, and other competing interests. If any consensus resulted from the Conference, it was that the health and education of women is a major determinant in improving the human condition. 
The debates in Cairo once again awakened the "catastrophist" and "alarmist" vision of global apocalypse. Neglect of population matters and ecological concerns is fraught with danger for the world community. But overstating and exaggerating the state of the environment and global overcrowding is certainly as dangerous, if not more so. The use of scare tactics often serves as an instrument of social control. Alarmist predictions and embellished descriptions of current conditions often lead to policies of improper force and coercion. Consequently, less attention is given to the policies which promote equity and democracy (Bahr, Chadwick, and Thomas, 1972: 6; Bailey, 1993: 168-178; Hartmann, 1995: 39,389).

In response to the doomsday philosophy displayed at ICPD Cairo, this paper explores four themes. First, the arrangement of social institutions, not nature, is the primary determinant in underdevelopment and poverty. Second, an expansion of human rights, especially the empowerment of women, may serve as partial remedy to the three problems of population, development, and the environment. ${ }^{2}$ Third, ceremonial encapsulation of technology is a major obstacle in improving the human condition. And fourth, democracy and a more equitable distribution of world produce are better remedies than draconian measures.

\section{THE UNITED NATIONS CONFERENCES ON POPULATION}

The United Nations International Conference on Population and Development (ICPD) in Cairo was the third meeting of its kind. The first meeting congregated in Bucharest in 1974 where a clear split developed between the more developed countries (the North) and the less developed countries (the South). ${ }^{3}$ The North took a Neo-Malthusian approach in suggesting the growing population was a major threat not only to development in the South, but also threatened the future of the North. In a surprise offensive, voices from the South suggested that the developed countries (particularly the United States) used the population issue as a means of avoiding the major issues which address the root cause of poverty. The South advocated a more equitable distribution of resources, a better balance of global political power, and more attention to the needs of the poorer countries. Noting that population growth rates fall as economies develop, they claimed rising economic development would become the "best contraceptive."

The second ICPD meeting was held in Mexico City in 1984. The countries of the North were much better armed the second time around. They took a position which acknowledged the impact of development on population growth; yet, they charged that the more important path of causation is from population to development. The 
return to Malthusianism was awkwardly coupled with a strong anti-abortion stance. The influence of the American anti-abortionist lobby led Ronald Reagan to withdraw American support for any population program that involved abortion (directly or indirectly) as a means of birth control (Correa and Reichmann, 1994: 1-7; Hartmann, 1995: 128-148; Camp, 1990: 126-127).

The third meeting (in Cairo) returned to the theme of development as the most important factor in population growth. It integrated the major issues of population, development, and the environment with the "advances of women through education, health and nutrition." (United Nations, 1995: 6) According to the UN Report, there are four requirements for any program of population and development: (1) gender equality and equity, (2) empowerment of women, (3) the elimination of violence against women and (4) the ability of women to control their own fertility:

Advancing gender equality and equity and the empowerment of women, and the elimination of all kinds of violence against women, and ensuring women's ability to control their own fertility, are comerstones of population and development-related programmes. The human rights of women and the girl child are an inalienable, integral and indivisible part of universal human rights. The full and equal participation of women in civil, cultural, economic, and political life, at the national, regional and international levels, and the eradication of all forms of discrimination on grounds of sex, are priority objectives of the international community (United Nations, 1995: 449).

The issue of equality between the sexes (including sexual freedoms and birth control) created a major schism between some of the Moslem nations and the feminists. Saudi Arabia led a boycott of the meeting and was joined by Sudan, Lebanon, and Nauru. The Vatican also registered its distress with the feminist position on reproductive rights.

Sonia Correa and Rebecca Reichmann (1994: 3-4) question how much of the resistance to changes in gender roles and reproductive rights is due to religion and how much is due to patriarchal dominance. They maintain "fundamentalism is not religious" but is rather a "political phenomenon" with strong policy implications at the national and international level. Homa Hoodfar (1994: 11) contends that the controversy has more to do with "the political and economic realities of a given society" than with religion. In this context, birth control/sexual freedom is more of a matter of social control than one of religion. 
The issue of population control crosses more than religious and cultural boundaries. The question arises as to whose population is to be controlled and who is to make the choice. Paul Ehrlich (1968: 1990) believes some countries are so far behind in the "food-population game" that there is no hope any amount of aid could ever help them. Other countries which are not as far behind in the "game" could only be saved through involuntary and coercive birth control policies. A danger exists that coercive population control could become "a govemment of the developing countries by the developed ones." (Feenberg: 1996: 277) Charles Maynes (1995: 44) wams of a trend toward viewing "disease-ridden, violent, and proliferating colored people" as the main culprit in a perceived population explosion.

\section{THE POPULATION QUESTION: EXPLOSION OR EXPANSION?}

For almost two centuries, the population debate has centered around the work of Thomas Robert Malthus. His bleak prognosis for humankind in the first edition of Essays on the Principle of Population was based on the idea that population grows at a geometric rate while food and the necessities of life grow at an arithmetic rate. Higher yields of crops per acre and the decline in the growth rate of population that accompanies economic development have severely challenged Malthusian theory. Nonetheless, the rhetoric of the "dismal" social scientist (and part-time parson) left the world with a two-hundred year hangover and has manifested itself in the contemporary population question.

Malthus viewed the plight of the poor as being the result of their inability to practice self-discipline and moral restraint. ${ }^{6}$ Any attempts to help the poor would only make their problem worse. Nonetheless, birth control was the "improper means to hide the consequences of an irregular connection" and Malthus claimed to have opposed it on moral grounds. His opposition to birth control had more to do with his resistance to sexual freedoms for the poor than moral considerations.

Malthus further concluded that there was a natural reason why "a breach of chastity" is far more disgraceful on the part of a woman than a man. The natural reason springs from the notion that women cannot be expected to "have resources enough to support their own children." These arguments for social control are masked as "natural" outcomes based on "moral" principles. In fact, there is no reason in nature or in moral theory which explains the poverty of women. Discretionary policy, not nature, denies the access of women to sufficient income to raise children and to enjoy the basic social goods of society. Gender inequality, 
as well as all other forms of inequality, is a basic reason for overpopulation and underdevelopment.

As seen at the ICPD Cairo, the Neo-Malthusian approach to population and poverty relies heavily upon "scare tactics" similar to those of the original dismal philosopher. It is true that world population now stands at 5.7 billion with some 100 million being added each year. The United Nations Population Fund predicts world population to be 8.5 billion by the year 2025 . These numbers are staggering when viewed through the eyes of population alarmists. ${ }^{7}$ The call for alarm notwithstanding, these numbers can be less threatening when analyzed from a different standpoint.

In Apocalypse Not, Ben Bolch and Harold Lyons (1993: 26) divided the current world population by the land area of Texas. They found that every person in the world could be placed in the state of Texas in a house with a floor plan of 1400 square feet. The Bolch and Lyons analysis is admittedly simplistic but no more so than predictions of the population control establishment. Wallace Kaufman best puts overcrowding in perspective when he said:

Fortunately population growth is likely to level out between 12 and 15 billion midway through the next century. For a little perspective, we should note that all of these people could fit in an area twice the size of Rhode Island. That would be shoulder to shoulder, but the rest of the world would be empty. More rationally we could fit in a futuristic megacity or "arcology", the size of Texas, with the rest of the world empty. I would not want to live there, but I offer the picture to point out that even 15 billion people would not populate the world as densely as ants in an anthill (1994: 176).

Contrary to the claims of the population establishment, persistent famine is not the result of overpopulation. It is invariably the failure of major social institutions and the result of civil wars, wars, or ineffective public policy. Nor is hunger the result of a lack of resources. Japan has virtually no natural resources, little arable land, and a very large ratio of population to land space but faces no problem in feeding its population. Distribution of democratic rights and global entitlements are much more important determinants than population (Hartmann, 1995: 17, 292). Thus, the issues of survival and the quality of life have more to do with ideology than with natural barriers to progress and development. 


\section{BARRIERS TO DEVELOPMENT : MENTAL OR PHYSICAL?}

A recurring theme in the issue of economic development is centered around the notion of resources. The view of resources as being finite (and thus fixed in nature) engenders fears and doubts about the possibilities of future economic development. A growing population puts pressure on a dwindling resource base in this scenario. ${ }^{9}$ A world of finite resources translates into a call for population control, zero economic growth, and austere economic policies derived from an elite group who decides what is to be done.

The functional view of resources presents a markedly different scenario. Resources are not fixed by nature; they are a function of technology. In other words, resources spring from a state of mind rather than from a state of nature. Human ingenuity is unlimited and historically has ensured the availability of a continuous resource base. Resources become obsolete before they are exhausted (DeGregori, 1985; 1987; Zimmermann, 1951).

Warnings of resource depletion have haunted humankind for hundreds of years. Stanley Jevons (1865) predicted the depletion of coal in England over a century ago. At about the same time, the United States Department of Interior predicted the exhaustion of timber (Bailey, 1993: 66-67). Jeremy Rifkin (1980) predicted the exhaustion of petroleum by 1990. What each of these "catastrophists" overlooked was the role of technology. (Horner, 1989) Technological change brought about a larger, not smaller, supply of coal in the century following Jevons' forecast. The same was true for petroleum. Supplies of oil and natural gas glutted world markets within a decade of Rifkin's declaration that the age of the fossil fuel economy was over.

Tales of doom continue to arise in spite of the miscalculations of prophets of worldly demise (Ehrlich, 1968;1990; Meadows and Meadows, 1972). "Carrying capacity", "sustainable development", and "population explosions" are just a few of the notions presented at the ICPD in Cairo which recommence the idea that the exhaustion of finite resources will lead to ultimate chaos and doom. The focus is misplaced. As Thomas DeGregori notes:

Technology, resource creation and emergent evolution engender not a world of an unknown future but of emerging possibilities. Our destiny is not in being but in becoming. . . . Those who would turn us aside out of some fictitious fear of resource exhaustion would protect us from the dangers of the unknown but would also deny us its possibilities. 
The liberating idea of technology and resource creation is the human potential that is there, if we are aware of it and if we frame our policies accordingly. We will exhaust resources if we exhaust creative imagination (1987: 1260).

Any discussion of economic development cannot be divorced from environmental concerns. Women have an important role to play in this discussion given their unique relationship with the environment.

\section{ENVIRONMENTAL CONCERNS: TECHNOLOGY AND THE ROLE OF WOMEN}

There is a recurrent notion that economic progress always brings with it an increase in environmental degradation. Environmental degradation and economic progress are not necessarily complementary outcomes. There exists a romantic notion that living conditions were better in the "old days" before the onslaught of the automobile and the modern corporation. DeGregori describes the "horse economy" of the cities at the turn of the century:

The horse was rightly seen as a health problem that some thought the automobile would cure. Each horse discharged gallons of urine and nearly twenty pounds of fecal matter on the streets daily. The manure piles drew flies, gave off a foul odor, and formed a breeding ground for diseases. Streets were cesspools when it rained and pulverized dung blew into pieces in dry weather [and] . . . powder irritated respiratory organs (1985: 182).

The average life expectancy has risen during this century despite an increase in the use of chemicals, the advent of automobile pollutants, and the dangers of carcinogens. Many cities and countries with slow growth rates suffer pollution far beyond what is seen in the more industrialized countries.

Most confusion and fear concerning environmental degradation is due to a misunderstanding about technology and its problem solving capacity; consequently, the contemporary attack on modern technology is frequently misguided. Technology is not a "thing." Nor is it a piece of equipment. Technology is "our ways of knowing." 10 New technology certainly creates new environmental problems. But if the problems created by new technology are less severe than the 
ones it replaces, progress is said to have taken place. Women can play an important part in this progress, if allowed to participate.

Ariel Salleh (1994: 106-107) sees women as having certain knowledge and experiences which give them particularly important insight on the environment. Their experiences may arise from female body organs in the "interplay of birthing and suckling labor" or they may arise from their historic positions of providing "caring and maintenance" functions which serve as a "bridge" between men and nature. Other knowledge may arise from the traditional manual labor of women such as weaving, farming, and pottery. Two examples illustrate this view.

The introduction of chemical pesticides and high-yield fertilizers in the Philippines caused the eradication of inexpensive domestic foods such as snails, frogs, and fish. The chemicals also resulted in spontaneous abortions, vision problems, and severe skin irritations. After these chemical substances were banned, Filipino women employed native technology which was older but much more effective. They planted certain indigenous plants, which are natural pesticides, between various vegetable crops. The women now wash clothes with a coconut based soap, a natural pesticide for some plants, and use the water for crop irrigation. Their compost baskets serve the function of increasing the fertility of the soil and thus replace chemical fertilizers (Ayupan and Oliveros, 1994: 113-120).

During the $1970 \mathrm{~s}$, businesses in northern India quarried and processed chalk that was to be used in the manufacture of cosmetics. Upper income women were the primary buyers of the cosmetics. Severe deforestation and water pollution from chalk run-offs ensued. As a result, a direct conflict developed between the wants of wealthy women (make-up) and the needs of working class women and their families (food and sustenance). The narrow paths used by men to bring the chalk out of the foothills of the Himalayas on burros were the same paths being used by the local women farmers to haul produce and water. The female farmers often had to wait hours for the mule teams to pass. In response, the women altered the paths so that the pack trains experienced difficulty in passing and the powder business became unprofitable for that locale. Women now move freely on the paths. Trees stand again where once deforestation marked the points of excavation (Stone, 1989: 175-176).

Such success stories are rare but not because of the lack of skills or knowledge of women. Rather, it is because of the impediments placed in the way of women (and all disenfranchised groups). Most obstacles to effective policy toward population, 
development, and the environment are due to the "ceremonial encapsulation" of technology.

\section{IMPEDIMENTS TO THE EMPOWERMENT TO WOMEN: CEREMONIAL ENCAPSULATION}

Paul Dale Bush $(1986 ; 1987)$ recognizes the strategy to capture and control new technology. The "ceremonial encapsulation" of problem-solving technology protects vested interests as new technology is absorbed by the economic system only to the extent that it fits in with the ideology of the existing power structure. Ceremonial encapsulation prevents the community from enjoying the full potential of problem-solving processes. (Homer, 1991) By maintaining control over technological innovations, vested interests effectively control the future of the community. Bush's theory has important implications for the empowerment of women. The "son preference" practiced in India (and other countries) is a prime example of ceremonial encapsulation.

Sonia Correa and Rebecca Reichmann note that the amount of medical technology available is not always the main determinant in the status of women's health. Gender status, class, and race are sometimes more important factors. For example, the process known as "amniocentesis" was developed as a method to diagnose fetal genetic defects as well as the sex of the fetus. The technique has the propensity to add to the life-process and improve the quality of life. However, the ceremonial encapsulation of amniocentesis resulted in the use of the process as a means of gender selection in India during the 1980s. At the discretion of the father and not the mother, an abortion would be performed if the procedure indicated that the child was a female.

The Forum Against Sex Determination and Sex Pre-selection (1994: 78-87) argues that this type of process reinforces and legitimates orthodox prejudices which are an integral part of the oppression and discrimination against women. The language of the ICPD in Cairo is specific. The "son preference" in many countries is "curtailing the access of food, education and health care" (United Nations, 1995: 56).

The process of ceremonial encapsulation grips the environmental and population movements. Contraception technology has been encapsulated by those who are more motivated by "population control, prestige, and profit" than by the needs of those in the poor nations (Hartmann, 1995: 173-187). Non Governmental 
Organizations (NGO's) have played a major role in population control efforts. Hartmann fears that these organizations are dominated by middle and upper class whites who have little understanding of the developing world. She cites their confusion between defending the rights of population control with defending reproductive rights.

Many NGO's and local elites have pressured governments and communities to use particular birth control methods such as implants (Norplant), Inner-uterine devices (IUD), and injectable hormones (Depro-Provera). These methods reflect the values of the countries which developed them where frequent and regular monitoring is commonplace. Using these methods in the poor countries poses greater health risks as most women are not able to have regular visits with physicians; nor are these women as well informed about the dangers of using the techniques. ${ }^{11}$

Hartmann (1995: 139-143) also warns of problems in the environmental movement. Many in the population establishment and environmental groups treat women as an "undifferentiated mass." Recognition of the differences between them (rich vs. poor, rural or urban, black or white) is essential for the empowerment of all women, not just the affluent. The same is true for the differences between men:

How many poor women of color, for example, support the position of the many rich white environmentalists that high fertility is the main cause of the environmental crisis? There is no consensus here, even by the wildest stretch of the imagination ... In the population consensus poor men's oppression, while scarcely mentioned, is also not linked in any way to rich men. In a new twist on male bonding, the corporate executive and the landless laborer are both just "men", in the same way that Imelda Marcos and a poor Filipino plantation worker are just "women" (op cit: 136).

Technological innovations and better education have the propensity to add to the life process and improve the human condition for women. New knowledge is permitted to the extent that it does not disrupt the existing value structure. The ceremonial encapsulation of technological innovations in the industrial arts denies the community, especially women, the full extent of problem solving knowledge. New technology is captured by a patriarchal system enabling males to take over tasks which had been traditionally performed by women at home. The displacement of women locks them into the secondary labor market (the informal sector) where there is little upward mobility. Any mobility tends to be from one low paying job to another (op cit : 1995: 45-47). 
The mechanization of agriculture has been ceremonially encapsulated in some cases. Technological innovations have the potential to narrow the biological physical differences between men and women. Patriarchal systems have captured the innovations and distributed most of the gains to men. Instead of allowing women to work in agricultural jobs which, heretofore, would have been beyond their physical capabilities, the work is given to men and more women are displaced (op cit : 1995: 44).

\section{CONCLUSION}

The growth in population over the last half-century is not solely the result of rising fertility rates. It is better explained by longer life expectancies and the decrease in infant mortality. Population growth decreases as a result of economic development; the direction of causation is not the other way around. The world is not running out of resources. History has shown that technology, price effects, and substitution effects have rendered resources obsolete before they were exhausted. Living within limits set by a belief in finite resources is the path to extinction and not the path to perpetuation of life. Environmental degradation plagues the earth today but the same was true in bygone years. Ecological improvements come not from containing technology, but from preventing the ceremonial encapsulation of technology by vested interests; that is, those who protect the elite at the expense of the less fortunate.

Policymakers must choose between democratic reform and draconian measures. The empowerment of women is more ethical than the draconian measures forwarded by the population establishment and the limits-to-growth advocates. Establishing entitlements of all people to food and medical care is more likely to bring about better conditions than a slow-growth or no-growth policy. The extension of political and economic rights for women will bring about more effective decisions concerning the environment than will coercive economic and social policy. More education and better health for women provide more of a chance for economic progress, than does compulsory population control.

Many well-intentioned and concerned people attending the ICPD in Cairo were involved in a genuine quest to find the correct balance with respect to population, development and the environment. Few of them will be among those involved in ultimate decision making and policy implementation. The decision makers are more likely to come from the ranks of local elites, the environmental aristocracy, 
and the population establishment. Their tools of persuasion will be tales of environmental ruination, massive overcrowding, and ultimate demise. They will not be as concerned with the empowerment of women and other disenfranchised groups as they will be with maintaining status and power.

A moral and ethical approach to global problems is based on democracy and in optimism. Sustainable economic progress commands an equal partnership between the North and the South, men and women, and the rich and poor. Solutions to contemporary challenges thrive in the waters of freedom, mutual respect and love, but die in a flood of xenophobia, racism, and chauvinism.

The success of modern technology and economic growth deserves as much attention as the failure. Optimism does not draw as much attention in the short run as does tales of doom and catastrophe. But neither does it pose the almost certain long-run hardship of pessimism. Perhaps Wallace Kaufman expresses the spirit of this paper when he says:

We have unleashed dangerous forces in the world. We created them and we understand them a lot better than primitive people understood the weather or the waxing and waning of the animal populations they hunted. We are in no worse position than humans ever were. We have lost some things and gained much. We may regret the loss of Glen Canyon or the darkened midwestern sky. But we don't regret the passing of yellow fever, malaria, or bubonic plague. Few people really want a simpler life. We may turn down the thermostat five degrees, but we don't take out the heat pump. We all want more, for ourselves and for the rest of the world, because we know that it is the way to peace. And we know it is possible. Now that we know the freedom of the human mind is more important than any natural resource, no insurmountable obstacle exists to continued improvement in the quality of our lives and the way in which we manage the natural world (1994: 181).

\section{ENDNOTES}

'Betsy Hartmann $(1995$; 134) believes that "poor men need to be empowered too, but not in the traditional, patriarchal sense." Women can be empowered only to the extent that they enjoy equal rights with men at home and in the community at large. ${ }^{2}$ The ICPD Report cites three factors necessary for the empowerment of women: (1) Mechanisms are to be established for equal participation and representation at 
all levels of the political process and public life (2) Promotion of women's education, employment and skills and (3) Elimination of all discriminatory practices.

"The term "North" is synonymous with "developed nations" and "Western nations." The term "South" is synonymous with "developing nations" and the "Third World." "There was a special emphasis in Cairo on the discrimination toward girl children. Included in this emphasis is the equal access to health for all children. The Report also admonished all countries to stop the sexual mutilation of female infants (United Nations, 1995: 56).

${ }^{5}$ As to whose population is to be controlled, there is a wide range of candidates: baby girls in the preference for male babies; ethnic groups within a society that are outside the "norm"; or the poor in developing countries. Some in the developing world ask if there should be the same limits on the number of American babies who will grow up to consume a disproportionate amount of the world's resources.

${ }^{6}$ Malthusian theory serves as more of a call for social control than one of population control. Malthus was reacting to the French Revolution where the landed aristocracy was overthrown. Neo-Malthusian theory is primarily an invidious attack on the poor masked as concern for the South.

${ }^{7}$ At the beginning of the period known as the first Industrial Revolution, birth rates were high as was the mortality rate. The final stages of the Revolution witnessed declining birth rates as well as declining mortality rates. Population growth is not necessarily mutually exclusive with long-run economic developmen

${ }^{8}$ Amartya Sen (1981) contends the food supply has little to do with famine and poverty. He notes that a major famine has never persisted in democratic societies.

To paraphrase Julian Simon, accepting this view requires the world to carefully budget its time and natural resources over the next few million years in order to prolong the inevitable depletion of resources (Simon, 1993: 446).

10 Paul Krugman (1994: 66) credits "increases in knowledge" as the main forces behind the growth of the Pacific Rim countries in recent times as well as Communist countries during the 1950's and 1960's.

"Many population control programs are viewed as culturally biased by women in the developing nations. The emphasis on Westem individualism may overlook the role of culture. Choice must be viewed in terms of context. The "individual choice" of women in some societies may actually be the choice of the existing framework of power (Correa and Reichmann, 1994: 77). 


\section{REFERENCES}

1. AYUPAN, L.B. and OLIVEROS, T.G. (1994). Filipino Peasant in Defense of Life in Close to Home, Ed. Vandana Shiva (Philadelphia PA: New Society Publishers), 111-120.

2. BAHR, H.M. and CHADWICK, B.A. and DARWIN L.T. (1972). Are Proposals for Population Control Premature? in Population, Resources, and the Future, Ed. Bahr, H.M. Chadwick, B.A. and Thomas, D.L. Provo UT: Brigham Young University Press, 1-12.

3. BAILEY, R. (1993). Eco-Scam. New York: St. Martin's Press.

4. BLOCH, B. and LYONS, H. (1993). Apocalypse Not Washington DC: Cato Press.

5. BUSH, P.D. 1986. "On the Concept of Ceremonial Encapsulation" The Review of Institutional Thought. 3 December: $25-48$.

6.

(1987). Theory of Institutional Change. Joumal of Economic Issues 21 (September): 1075-1116.

7. CAMP, S.L. (1990). Population: The Critical Debate. Foreign Policy 90. Spring: 126-144.

8. CORREA, S and REICHMANN, R. (1994). Population and Reproductive Rights. London: Zed Books.

9. DEGREGORI, T. (1985). A Theory of Technology. Ames IA: Iowa State University Press.

10. (1987). Resources are Not. They Become. Joumal of Economic Issues 21 September: 1241-1264.

11. EHRLICH, P. (1968). The Population Bomb (New York, Ballantine Books).

12. EHRLICH, P. and A.(1990). The Population Explosion (New York: Simon and Schuster).

13. FEENBERG, A. (1996). The Commoner-Ehrlich Debate: Environmentalism and the Politics of Survival in Minding Nature, Ed. David Macauley. New York: Guilford Press, 257-282.

14. The Forum Against Sex Determination and Sex Pre-selection. (1994). Using Technology, Choosing Sex in Close to Home, Ed. Vandana Shiva. Philadelphia PA: New Society Publishers, 78-87.

15. HARTMANN, B. (1995). Reproductive Rights and Wrongs. Boston MA: South End Press.

16. HOODFAR, H. (1994). Devises and Desires: Population Policy and Gender Roles in the Islamic Republic. Middle East Report 24. SeptemberOctober: 11-17. 
17. HORNER, J. (1991). "The Case of DAT Technology" Journal of Economic Issues 25 (June): 449-458.

18. (1989). The Role of Technology. 23 Journal of Economic Issues 23 June: $579-586$.

19. JEVONS, W. Stanley. (1865). The Coal Question. New York: A.M. Kelley, reprinted in 1965.

20. KAUFMAN, W. (1994). No Turning Back. New York: Basic Books.

21. KRUGMAN, P. (1994). The Myth of Asia's Miracle. Foreign Affairs 73 November/December : 62-78.

22. MALTHUS, T.R. (1803). On the Principle of Population II (London: J.M. Dent, reprinted in 1914).

23. MAYNES, C.W. (1995). The New Pessimism. Foreign Policy 100. Fall :33-49.

24. MEADOWS, D.H. et al. (1972). The Limits to Growth. New York: Universe Books.

25. RIFKIN, J. (1980). Entropy: A New World View. New York, Bantam Books.

26. SALLEH, A. (1994), Nature, Woman, Capital, Labor: Living the Deepest Contradiction in Is Capitalism Sustainable? Ed. Martin O'Connor. New York: Guilford Press, 106-124.

27. SEN, A. (1981). Poverty and Famines. Oxford: Clarendon Press.

28. SIMON, J. (1993). Population Matters. London: Transaction Publishers.

29. STONE, B.W. (1989). Celebrating Embodied Care: Women and Economic Justice. in Reformed Faith and Economics Ed. R. Stivers. New York: University Press of America, 171-182.

30. UNITED NATIONS. (1995). The Advancement of Women: 1945-1995. New York: United Nation Office of Public Information.

31. ZIMMERMANN, Erich W. (1951). World Resources and Industry. New York: Harper and Brothers. 